\title{
Social Discrimination of Religious Minorities in Argentina: An Exploratory Study of Religious Discrimination Applied on Jehovah's Witnesses
}

\author{
Esteban Maioli \\ Department of Political Science and Sociology, Latin American School of Social Sciences(FLACSO), Argentina
}

Copyright $(2016$ by authors, all rights reserved. Authors agree that this article remains permanently open access under the terms of the Creative Commons Attribution License 4.0 International License

\begin{abstract}
Institutionalized religious discrimination forms a matrix of meanings from which it is interpreted and re-signified all social practice. This horizon of meaning, almost invisible at the level of the formation and use of common sense, makes religious discrimination in a persistent and complex social phenomenon. The impairment in the enjoyment of certain fundamental freedoms, among which is necessary to place religious freedom, is particularly significant for religious minorities, who are more likely to be subject to discriminatory social practices under their subordination against the existence of a confession or dominant religion. For some religious communities it is easier to be accepted by the social environment, at least in appearance. In the case of Jehovah's Witnesses, although it has legal recognition by the State, it is also true that the mass media convey a distorted view of their purposes and ways of life (Shammah [1]). Moreover, the discrimination of which are subject to Jehovah's Witnesses needs to be analyzed, in political terms, in the broader context of the tension between the forms of linkage between the State and the various minorities are integrated into the social fabric. Thus, the homogenization of the different identities and the formation of a "national" one, in order to concentrate diversity in unity, has been the strategy that the Argentine State has deployed from the moment of its formation, assuming the trend of the French model the laicité (Donatello [2]).
\end{abstract}

Keywords Religious Discrimination, Jehovah's Witnesses, Discriminatory Matrix, Discriminatory Social Practice, Religion

\section{Introduction}

Institutionalized religious discrimination forms a matrix of meanings from which it is interpreted and re-signified all social practice. This horizon of meaning, almost invisible at the level of the formation and use of common sense, makes religious discrimination in a persistent and complex social phenomenon. The habituation of discriminatory behavior leads to a naturalization of exclusive original meaning. Thus, religious discrimination is an embodiment of social segregation, establishing differential treatment on members of certain religious confession and denying or limiting access to certain rights and guarantees. This impairment in the enjoyment of such fundamental freedoms, among which is necessary to place religious freedom, is particularly significant for religious minorities, who are more likely to be subject to discriminatory practices under their subordination to the existence a confession or dominant religion.

Moreover, from the last three decades, the religious map of Argentina has undergone transformations. We are witnessing a simultaneous process of individuation and privatization of religion, together with a progressive externalization of religious manifestations in public space. This double movement, paradoxical and complementary, forms the stage on which the mundane act of religious minorities unfolds. All within the broader framework of a "Catholic secularism" (Mallimaci [3]), consisting of a set of non-practitioners that brings together diverse "disbeliefs" (Mallimaci [3]). The paper aims to review the discriminatory social practices applied to religious minorities in Argentina institutional network, specially focused on Jehovah's Witnesses.

\section{Some Initial Approaches}

In the sociological tradition concerned about the issue of social discrimination there are different views for analysis and theoretical treatment of the subject. One line of research considers discrimination as an individual behavior which somewhat limits the opportunities for action of a social group. This form of approach to the phenomenon, individualistic, is insufficient to understand in depth a multi-causal as is discrimination phenomenon. On the other hand, another line of research considers that discrimination 
must be understood as a complex system of social relations that produces inequalities between groups, generating as a result a set of social products objectified manifesting such a situation of origin (Pettigrew and Taylor [4]).

In turn, it is possible to recognize in the theoretical tradition linked to the subject (Pettigrew [5]; Antonovsky [6]; Hepple and Chourdhurry [7]; Robbers [8]) a general characterization of discrimination based on two social types: direct discrimination and indirect discrimination. Direct discrimination is unequal treatment of an individual or group; and such treatment is explicitly founded on discriminatory criteria, i.e., considering a particular social group lower relative to each other from different foundations, including the belief or religion. Meanwhile, indirect discrimination is the perpetuation of the original direct discrimination. In this sense, the effects of direct discrimination form the basis for subsequent actions of other social groups, through habituation of behaviors that make up an institutional order. In turn, indirect discrimination in institutional apparatus sets the basis to such fertile ground for growth and maintenance (Feagin [9]), giving rise to the phenomenon of institutionalized discrimination. In turn, "it is fundamentally discrimination legislation; structural network operates largely independently of the "tastes" and attitudes present the dominant group. Hence, models primarily based on individual prejudice or the "rationality", whether psychological or economic, uniformly minimizes and simplify the phenomenon "(Pettigrew [5]).

\section{Religious Discrimination}

It is important to recognize that all known human societies, at all times, have exercised acts of social differentiation. Recognition of identity requires the construction of an otherness, based primarily on the differences. However, it is necessary to recognize a fundamental distinction between this form of social differentiation, known as heterophobia, and forming the "other" out of fear or a sense of confusion against the existence of different subjects oneself (Todorov [10]). Discrimination is associated with another form of racism, known as racialism, and that relates to the ideological construction of otherness, which is presented as hierarchical and competing entities (Grüner [11]). Racism and discrimination are formed as modern phenomena linked to the emergence of the nation-state, and they tend to segment the entire human population into smaller groupings (and opposed to each other) from a set of stereotypes and constructions ideological (Bauman [12]).

In general, all international documents, declarations and conventions protect the right to religious freedom and therefore prohibit religious discrimination. In particular, the United Nations Declaration on the Elimination of All Forms of Intolerance and of Discrimination Based on Religion or Belief (1981) considers "intolerance and discrimination based on religion or belief any distinction" as any exclusion, restriction or preference based on religion or belief and whose purpose or effect nullification or impairment of the recognition, enjoyment or exercise on an equal footing of human rights and fundamental freedoms" [13].

Religious discrimination, whatever may be its kind, is a series of demonstrations of various nature and scope. The current multicultural reality (Grüner [11]) causes an unusual touch of various highly heterogeneous groups, at least in terms of ethnicity and religious affiliation (Domenech [14]). This contact often reveals certain prejudices and stereotypes founded on wrong and unfounded ideas, which in many cases lead to various forms of social conflict, segregation and exclusion. Of no less importance is the validation that is given to racism and religious discrimination from the intellectual and scientific field. In this sense, it is not difficult to find in the literature pseudo-scientific justifications of racism, religious intolerance and other discriminatory practices based on old theories that were already considered obsolete, because of its discriminatory use of inappropriate stereotypes and lack of substantiation tested (Lischetti [15]).

There are many available research works about discrimination based on grounds of religion or belief. The general approaches are linked to the investigation of causes and consequences of religious discrimination (Fox [16]; Juergensmeyer [17]; Greenwalt [18]). The link between political and religious discrimination is also analyzed in several specialized works on the subject (Little [19]; Turner [20]; Haynes [21]). Several researches highlight the need for an interdisciplinary approach to the issue (Hagel [22]; Lundahl and Wadensjö [23]). However, there is a significant amount of research that assumes the sociological perspective (Blancarte [24]; Horbath [25]; Gracia [26]). In all of them, a general view on the phenomenon of religious discrimination and its relationship to the different religious expressions and areas of occurrence is presented.

There is now a strong debate about the relationship between religious discrimination and the secular status of the state (Blancarte [27]). Certainly, the idea of a secular state does not come into opposition with the possibility of full freedom of exercise of belief and worship of some believers. The Argentine case cannot be qualified lay in the liberal sense of the term (Villalpando et al [28]). While the Argentine State maintains financially to Catholic worship, it is perceived as a "secular state of Catholic culture" (Mallimaci [29]).

For some religious communities it is easier to be accepted by the social environment, at least in appearance. In this regard, there are at least three significant events to facilitate the acceptance of religious communities in the wider social spectrum: a) legal recognition of the religious community by the State; b) the influence of the mass media, who "accept" certain religions; and c) the absence of certain preconceptions, prejudices or value judgments formed without prior knowledge of religion or belief in particular (Rodriguez Salazar and Garcia Curiel, [30]).

Social discrimination is a phenomenon long lasting and it has profound implications for the social life of people. However, in general, it has been a phenomenon difficult to 
define. Discrimination takes on different meanings, and its polysemy condition leads to consider discrimination as a great scope of practices and consequences. Following Rodriguez Zepeda [31], the first possible meaning of the term recognize discrimination, called lexical or lexicographical, it is the one that gets the sense of the term in its meaning for the common people. Thus, discriminate means to separate, distinguish or differentiate one thing from another. There is not here any assessment, since the action does not involve a selection criterion of the grounds in securities of any kind. Indeed, this sense does not support the connotation of political intent that assumes the term in another of its meanings. The second most widespread meaning of the word refers to an asymmetric relationship between individuals or groups, as involving an inferior treatment based on differentiation for some specific criteria, be it race, religion, age, gender or any other. Discrimination understood in this sense implies the existence of a subject or group refers to an element of supposedly superior differentiation from other subject or group, holder of said element or another linked, supposedly inferior. Discrimination is, therefore, a particular social relationship where mutual orientation of the behavior of agents is conditioned by certain prejudices or negative stereotypes, many of them forming stigmas that characterize social interaction.

Faced with this kind of definition, Rodriguez Zepeda said that "we need a piece in the lexicographical definition of discrimination, namely the reference to specific impact on certain own fundamental property of moral or legal subject suffering discrimination and who they are at risk "(Rodriguez Zepeda [31]). Therefore, the author argues that the definition of discrimination is understood only supplement whenever you understand what is the damage that such process results in the other or others. In this regard, it states that the relevant semantic field to form an acceptable definition of discrimination is the fundamental rights of the person. Therefore it argues that the lexical meaning of the term discrimination partially accounts for the phenomenon, while not indicate the actual or potential consequences in relation to a series of subjective rights considered essential and relevant social opportunities.

Thus, Rodriguez Zepeda leads the problem of discrimination in the field of legal regulations. He considers that non-discrimination "is the right of every person to be treated uniformly, without exclusion, distinction or arbitrary restriction, so that will make possible the use of their fundamental rights and freedoms and free access to opportunities socially available as long as a temporary preferential treatment to it or to its group affiliation is not necessary to replace or compensate for the historical damage and the situation of weakness and current vulnerability caused by previous discriminatory practices against his group "(Rodriguez Zepeda [31]).

Much of the specialized literature on the subject focuses on legal references of the problem of discrimination. Thus, it is understandable verify that a significant amount of theoretical work on the scope, characteristics and consequences of social discrimination and its related social forms is in the field of law. Some authors argue that the revision of the legal regulations implies, ultimately, an analysis of the political foundations on which this legislative structure (Rodriguez Zepeda [31]) stands. Ultimately, the legal definition creates the fiction of fixing something that is actually the product of relations of forces that are set in a specific social field (Bourdieu [32]). The normative definition of discrimination always stands on an evaluative statement expressing at that time and in that social space, a situation of force relations. Therefore, "our values, our institutions and our way of life are a form of political order among several possible and consensus they require cannot exist without an exterior that always make our liberal democratic values or our conception of justice are open to controversy "(Mouffe [33]).

To fully understand the phenomenon of religious discrimination, it is necessary to know the legal constraints that States establish on religious freedoms in order to ensure equal conditions for all citizens. In this regard, the revision of the international legal norms stands on the principles of constitutionalism and its close ties with contemporary democratic liberalism. Needless to say, the definition of constitutionalism is "accept the value that is implicit in it, a value that, in shorthand, we indicate in defending the rights of the person, the individual, the citizen" (Matteucci [34]).

In principle, and as the main element, it is necessary to recognize that freedom of religion, like any other freedom, it is not absolute, but rather, is regulated and limited by other rights. That is, freedoms are unrestricted, but the rights set clear limits on those freedoms, in order to ensure equal conditions for universal access to their benefits. In this central question, a plethora of criticism of religious freedom is located. For many, the secular state limits and prevents the exercise of religious freedom, while for others, it is precisely the enunciation of positive law in the field which allows fair exercise of religious freedom in the State (Blancarte [27]). Internationally, a regulatory body of considerable importance attached to the issue of social discrimination is noticed, although there is a notable lack of international agreements or treaties that address the issue of religious discrimination in particular, whenever you compare it to other equally important social issues.

\section{The Structural Dimension of Social Discrimination}

Retrieving the notion of social discrimination and conceptual narrowness with the legal definition, it is possible to notice in the literature generally "discrimination is confused with questions of subjective tastes, particular behaviors and even morally reprehensible excesses but democratically defensible freedom of expression" (Rodriguez Zepeda [31]). In this way, non-discrimination is 
considered a fundamental human right. A common mistake, at least in legal terms, is to confuse non-discrimination with a special group right, as a prerogative of minorities of any kind. Ultimately, this debate gets problematic implicit in the notion of equality, which must assume a complex and historical perspective, in order to avoid falling into misjudgments.

Non-discrimination is not a side or complementary, but a law establishing the democratic ideal of equality law. However, discriminatory social practices, often downplayed in their effects, are not considered as serious damage to the core of such invidious set. Therefore, the pernicious for the whole community and social groups affected character are not warned. At the same time, the identification of the State as ultimate guarantor of the legal structure does not problematize the fact that such State is a particular struggle of social agents with particular motivations, but collectively able to claim a particular interest. That is, the state legitimizes certain relationships of force and in this regard, institutionalizes social conflict.

Rodriguez Zepeda [31] states that discrimination can be understood as a peculiar form of social inequality. In the same vein, says that "in a formulation of regulatory cut, we could say that is a limitation on the access of people to basic commodities such as rights and social bases of self-respect (Rawls), the provision resources (Dworkin) or the development of basic capabilities (Sen) "(Rodriguez Zepeda [31]). Whatever be the selected argument, we conclude that social discrimination leads to a reduction in the quality and life expectancy of people who are stigmatized.

As a social process, discrimination must be considered as a phenomenon which is liable to change from the agency's ability to social subjects. Faced with the reification of institutions and its social consequences, a constructivist perspective on the phenomenon of social discrimination allows us to recognize the historical character, and therefore transformable it. Constructivist social scientists look also allows the implications think in patterns of meaning and subjectivity from the matrix discriminatory institutional structure.

Analysis of Hannah Arendt linked to social discrimination progresses, at least in part, in this sense of reveals discrimination as a social phenomenon capable of being modified (Arendt, [35]). According to its thinking, discrimination becomes ideology when it transcends the realm of politics and becomes a set of ideas that make an action guide and social policy for the whole of society. Beyond that its position is highly controversial and has been the subject of profound challenges, the greatest merit of Arendt's perspective has been having placed the investigation of racism and discrimination in their ideological and political dimension, i.e. as specific forms of self-defense social sectors. The theoretical perspective Arendt believes, therefore, that in the field of politics, the elimination of social discrimination is possible. However, in other social areas it's considered to be a permanent phenomenon. While people tend to exercise their sociability through the formation of homogeneous social groups, both in practices and values and beliefs, it is a self-identification as equal before some "other" necessarily different. In this dialectic reality, it is then the social basis of discrimination (Arendt [35]).

Arendt's argument certainly shows the advantage of considering that discrimination is a phenomenon can be eradicated. However, there is a certain "naturalization" of the social dynamics of discrimination for other spheres of social life. Constructivist look (Berger and Luckmann [36]; Bourdieu [32]; Giddens [37]) reinforces the idea of the productive and reproductive capacity of human agency in all spheres of action of the social subject, even in those more intimate.

Such a position, at least in the conclusions above, is represented by the economic approach to discrimination. Becker [38], undoubtedly one of its greatest exponents, believes that discrimination can be explained in rational-economic terms. To do this, he says the rationality and economic calculations differ from social stigma and negative stereotypes, the latter because of the discriminatory aspects behave irreducible phenomenon. Prejudices, says Becker, cannot be eliminated by institutional mechanisms, and thus directly affect the rational behavior of the subjects. Becker argues that the subjects do not always behave in rational terms, and under it, often lead their actions from irrational motives, such as prejudice or stigma. The argument of economic theory of discrimination suffers from the fact relegate to a realm of virtual naturalization developing a specific evaluative set on which negative stereotypes are built. The structuring and institutionalization of certain discriminatory social practices are the result of a legitimization and sedimentation of social behavior and historically established (Berger and Luckmann [36]). It implies therefore legitimating strategies of positions and power relations that conform the objective structure from which a system of subjective dispositions for action and social interaction (Bourdieu [32]) are internalized.

Positions such as Arendt, Becker and many other theoretical perspectives (structural-functionalism, Frankfurt School) consider the reification of the phenomenon of social discrimination. In turn, in the treatment of thematic considerations discrimination as a structural phenomenon, taking in such an inaccessible characteristic aspect to social change abound. On the contrary, social constructivism is enlightening about the institutional dimension, thus revitalizing the capacity of transforming action of social partners.

The recovery of the institutional dimension of discrimination can also set the eminently social nature of the phenomenon. Therefore, individual practices perspectives fail to reveal the specific nature take discriminatory social practices. "Whoever does suffer discrimination because of their membership in a group, having been stigmatized; it is the subject of social contempt. In this sense, for analytical 
purposes, it is very important to note that discriminatory practices cannot be understood as individual or discrete phenomena, but should be viewed as updates of social series of conduct that support sociological records (Rodriguez Zepeda [31]).

Discriminatory phenomenology can lead to error consider discrimination from this point of view, as a result of acts of individual will, subject to the personality of the agent that discriminates. In this line of thought it is necessary to locate another aspect of study of discriminatory phenomena linked to the tradition of self-thinking of social psychology. This perspective emphasizes the subjective aspects of the problem. Dollard inquiries on the conformation of prejudice are pioneers in the field (Dollard [38]). In this sense, for this theoretical perspective, the study of prejudice as the basis of discriminatory social relations requires a study of psychosocial categories, specifically on the notions of frustration and aggression (Dollard [39]). Thus, discrimination is explained by the unresolved tensions arising from the deprivations and frustrations of childhood, which cannot be overturned by group membership, and therefore are located in another group, which is called the depositary. This way of approaching the phenomenon is limited, since it does not account for the social construction forms of prejudice, focusing only on the subjective appropriation of each social actor.

Like any social fact, its historical persistence implies that, once missing the executors of certain social practice, it is possible to note the continuation of the same and the emergence of certain social regularity in its modalities, scope and effects. One of the many peculiarities of the phenomenon of discrimination is that its consequences are reflected long and, in some cases, are much greater than those direct effects of the discriminatory act itself. The sociological perspective of discrimination has, incidentally, with the strong advantage of being able to analyze the phenomenon not only in terms of "economic" evaluation (understood as costs and benefits), but with a broader view, incorporating a greater amount of actors and social relations.

The term of indirect discrimination is commonly used in legal language both at international, regional and national levels; but ultimately, it denotes the structural dimension of the discriminatory phenomenon. Pincus [40] argues that the structural dimension refers to the type of political behavior of majoritarian institutions and the whole behavior of individuals who implement this policy and exercise control over the institutions. Overall, a discursive level are presented as neutral, while "generate a differential effect and / or harmful in minority groups" (Pincus [40]). Institutional analysis involve focusing attention not so much on the motivations, but rather on the effects of supra and subordination established between social groups, under the settling of such forms of social interaction.

The structural dimension of discrimination can be better recovered from the meaning given to that concept by the structuralism perspective of Levi Strauss [41]. Unlike other conceptions of structure, more anchored in materialistic settings (Marxist), the notion of structure acquires here a dynamic dimension, since it is possible to understand it as syntax social relations, scenario willing to significant transformations social agents embedded in them. The social structure is, then, an organized communication system of social relations. Materially affects, provided from the symbolic relationships between agents organize and crystallize different identities, world views and horizons of significance of their social practice (Levi Strauss [41]). Discrimination, "to be defined as a ratio of subjective order we can locate on the socio-symbolic or linguistic background, runs the risk of being seen as a determinant of social structure, when in fact it is" (Rodriguez Zepeda [31]). Social constructivism of Berger and Luckmann [36], from the notion of the social dialectic, only confirms and reinforces the material existence of symbolic relationships. That is, it can conceive discrimination as a subjective phenomenon and objective at a time.

This design enables, at the same time, find a common substrate for various discrimination basis. While it is true that social groups discriminated against by various foundations have specific characteristics that differentiate it is also possible to find common ground on which to classify, jointly, as discriminated social group, homosexuals, Jehovah's Witnesses, or obese (just as an possible example). In this sense, considering the stigma and negative stereotypes in the fundamentals of social discrimination, it is possible to recognize the structural dimension of the phenomenon again.

Retrieving the structural constructivist perspective of Bourdieu [32], the structural dimension also organizes relations of domination between different social groups. Under the social space occupied by social groups will be different life opportunities they possess. Therefore, the social field must be understood as a form of competition (game) that reinforces the dominance of one group over another. "An example of this conflictual dimension is given in the case of groups discriminated against by sexual preference or religious option. These minorities challenge with its moral and sexual choices, a dominant discourse about public decency that benefits traditionally discriminators groups. Such speech not only provides private symbolic satisfactions its defenders, but articulates and represents family, work or recreational relations in the social structure" (Rodriguez Zepeda [31]).

The structural nature of social discrimination implies that the whole of the social relations of the community are impregnated of it; thus institutionalizing social practices leading to a channeling both behaviors and expectations of those social agents involved in them (Berger and Luckmann [31]). Institutionalization works, therefore, not only as a mechanism of social control, while redirects behaviors within a discriminatory, but also as political matrix, while legitimizing the hierarchical ordering of a social group against another. Certainly, the structural extension of the phenomenon, however, admits vast spaces of individual freedom, and therefore it is understandable that there are, for 
various reasons, individuals or groups who may escape these institutionalized patterns of discriminatory behavior. However, the "usual" social rule is social reproduction of patterns and structural positions of people of their group affiliation, and under it, the habitus (Bourdieu [32]).

Rodriguez Zepeda [41] notes that there are several indications to consider structural discrimination as a social phenomenon. The first one is linked to the differentiation previously made between the phenomenon of direct discrimination and indirect discrimination. While the former is linked to consciousness and individual will to apply as determinants in shaping motivations for action, the second is related to the existence of a number of criteria or social norms, while tastes or socially extended preferences, and it assumes the form of a social or collective consciousness independent of individual consciences. Second, discrimination is a structure of social relations that determines a certain social order, establishing differences between groups and thus, determining the lifestyles of those who are belonging to them. It is on the basis of political design community. Third, the phenomenon linked to a series of clusters or ad scripted/acquired, with notable social differentiation elements are "unified" classifier under a common element: discrimination. Therefore, discrimination functions as social homologation mechanism differences from common sense are not contact points in the dynamic that assumes the discriminatory process.

At the same time, it is a violation of the fundamental right of equality, a fact based, at the same time, an element that allows characterizing discrimination as a structural phenomenon, despite differences within each social group discriminated against. On the other hand, it is a phenomenon of great material density, while determines a specific form of social relations. The subjectivity of social partners is transformed and in the same processes of social interaction, discriminatory social practices (Feierstein [43]) breed.

\section{Religious Minorities}

Generally speaking, religious minorities have been the historical origin of different minorities that have been undermined the enjoyment of their fundamental human rights. In this regard, the United Nations Rapporteur of the Sub-Commission on Prevention of Discrimination and Protection of Minorities defines a minority as "a group numerically inferior to the rest of the population of a State, in non-dominant position, whose members group, subjects of the state, have from the point of ethnic, religious or linguistically characteristics that differ from the rest of the population and show, if only implicitly, a sense of solidarity directed towards preserving their culture, their traditions, their religion or their language". Thus, the religious minority is defined by a number of subjective elements (bonds of social solidarity among its members, factors of social identification and specific socialization) and objectives (existence of a stable non-dominant social group is constituted from interactions supported on a religious motivation). Generally, a religious minority is also under other criteria, such as ethnicity or language.

In order to achieve some conceptual precision, it is necessary to distinguish the religious minority in a group or group belonging to a minority religion or church. Its members are often nationals who do not want to differentiate themselves from others, but rather that at some point have decided to adopt a religious denomination that does not correspond with most of his countrymen.

From the above definitions we can say that the religious minority group is distinguished from the "religious minority" in terms not want to set a clear difference to the population professes a majority creed. The religious minority group assumes specific differences in the framework of a plurality of religious expressions. Thus, the existence of these groups shows a religious diversity that may be can't be supposed if it's only considered the major religion in the country.

In the Argentine case, although the majority in terms of attachment to the Catholic religion, it is possible to recognize, therefore, a plethora of religious minorities as well as minority groups who profess a religion. For the purposes of this document, both terms will be considered similarly.

\section{The Argentinian Religious Reality and Discrimination}

From the last three decades, the religious map of Argentina has undergone transformations. The passage of Catholic hegemony to a growing religious plurality that cuts across all social classes warns. The emergence and remarkable growth of Pentecostalism, the groups Afro-Brazilians and the process of growing identity reaffirmation of Jewish and Islamic communities, forms a religious scene more heterogeneous than meets the eye.

Faced with the alleged Catholic hegemony, a plethora of new religious movements (Barrer [44]) appears. In the Argentine case, such religious expressions are represented by secular philosophical, non-traditional evangelical demonstrations and magical-religious cults. It should be noted that estimates of religious affiliation are difficult to estimate with certainty, since in Argentina national censuses do not collect data on religious affiliation of its citizens.

The phenomenon of discrimination, in general, and religious discrimination, in particular, is the result of a historical process in which the formation of the modern Argentine nation-state has had a major participation. The formation of a national identity led to the identification of an otherness built on certain special criteria. In this sense, the historical past of Argentina is contradictory. Although from the normative slavery was banned earlier, the effects of discriminatory social practices lasted for long. In the religious institutional level, the Argentine nation-state proclaimed early as respectful of religious freedom. The Constitution, adopted in 1853 and amended in 1994, said the preference for Catholic worship, giving rise to a freedom of 
worship, without equality of worship (Bidart Campos [45]). Beyond this, the Constitution of 1853 contained at least three issues that could be considered discriminatory: the conversion of indigenous peoples to Catholicism; the requirement that the President and Vice President of the Nation were Catholics; and the "Patronato" regime (Villalpando et al [28]). After the 1994 amend, most of these issues were modified. However, only the Catholic Church receives support and state subsidies as a religion, as opposed to any other religion, even registered in accordance with current regulations (Mallimaci [29]). This official support to the Catholic religion is one of the strongest claims of discrimination by members of other religions, particularly Protestant (Report of the Special United Nations Rapporteur on freedom of religion or belief).

\section{Discriminatory Social Practices}

It should be understood by discriminatory social practice any action to create or assist in the dissemination of stereotypes of any group for real or imaginary characteristics, whether the type they were, and are linked to ascribed or acquired characteristics (Villalpando et al. [28]). It should also be considered discrimination any act of harassment, abuse, isolation, aggression, segregation, exclusion and marginalization to any member of a grouping on grounds of real or imagined belonging to that grouping. Discrimination means, therefore, the peculiar act of distinction, whether legal, economic, religious, labor, gender, service delivery, a member of a grouping, creating the effect of impeding or cancellation of the enjoyment and exercise fundamental rights and fundamental freedoms.

In the case study (Jehovah's Witnesses), many of their fundamental rights have been canceled because of their religious belief. In education, Jehovah's Witnesses are stigmatized and even have no access to educational awards due to the performance of religious practices found according to their religious ideology. In the workplace, many Jehovah's Witnesses have been fired and lost their jobs because of their beliefs. Moreover, many believers of this religion have been subjected to imprisonment during the last military dictatorship in Argentina, because of his conscientious objection to accept certain practices (as part of the conscript army). Many of them have been persecuted by the state. Thus, it is stated that the enjoyment of certain fundamental rights is not assured in the Argentine institutional system for those who profess this religion.

The relevant analysis of discrimination should not focus on victims or groups affected by acts of social segregation, but rather discern what facts or phenomena concur that society exerts on such groupings discriminatory social practices (Feierstein [43]). In everyday life, religious communities face diverse and varied discriminatory practices. Some of them, according to the postulate by Scharf [50], are: a) Places of worship or worship; b) Burial rituals; c) Appointment of religious leaders; d) Funding of religious communities; e) Religious publications and production of editorial material.

In addition to the implications for the religious community discriminatory practices, there are also acts of discrimination which are aimed at individual subject, the believer. Many of these acts are the result of regulatory and institutional structures in the country that hosts; but many others stem from other reasons, such as indifference, intolerance or lack of knowledge about the belief system. In everyday life, individuals also face different discriminatory practices. Some of them, according to the postulate by Scharf [50], are: a) Access to services; b) Dress code; c) Worship practices.

\section{Jehovah's Witnesses}

The following presents the results from non-participant observation, documentary recompilation and qualitative interviews done during field work since January 2014 until August 2015. Sample of interviewed persons was designed under theoretical criteria.

Members of the Society of Watchtower Treaties are known generally as Jehovah's Witnesses. This religious community is born in the late nineteenth century, when its founder, Charles Taze Russell in 1877 published his first book, The Object and Manner of the Lord's Return. Russell religious training was heterogeneous, although it was mostly Protestant. He went through various communities linked to Presbyterianism and Congregationalism, if they were well its links with members of Adventism which generated a greater impact on him (Romero Puga y Campio López [46].

The origin of the Jehovah's Witnesses should be placed, then, in those years, when some differences on the criteria of interpretation of the Bible generate a break with Adventists. This small circle of followers founded a club study of biblical texts, called "The Bible Students" and concluded from their studies that by the year 1874 a fundamental fact would occur: the coming of Christ and the founding of a new world. The arrival of that date and the fact that were not produced the predicted events did not lead to the completion of the study group, but on the contrary, a certain radicalization of its research and interpretation, all aimed at trying to identify the reasons miscalculation of previously committed. During this stage they begin to develop a set of theological products that will be the primary basis of all future beliefs of Jehovah's Witnesses, and place them in the whole of postprotestantes (Beckford [47]).

From the publication of his first book, Russell lays the foundation for the characterization of Christ that distinguishes it from other Protestant groups, particularly the spiritual and intangible nature of his body, why coming to establish his Kingdom it would not be directly observable for all men.

Year 1879 sets another milestone for the elementary religious community, as both Russell as another set of his followers publish the first issue of Zion's Watch Tower and Herald of Christ's Presence. This first edition has more than 
six thousand copies and is the basis on which then the contemporary organization of the association will rise. However, it will be just five years later, in 1884, when the community is registered as a religious society non-profit, under the original name of Zion's Watch Tower Tract Society (Tract Society Watch Tower Zion), a name which then it will be modified in 1896, when he assumes the current name Watch Tower Bible and Tract Society.

The development of the Society was extremely fast and powerful. While only a few years, sermons were published in more than four languages, which were published in three thousand newspapers in the United States. On the other hand, during those years, many books and booklets (calculated in millions) were distributed around the world. Slowly but steady pace, the Company acquired an international character. Year 1916 is a time to break Jehovah's Witnesses, since the death of Charles Russell occurs. The succession was not complicated; with the death of the founder, Joseph Rutherford takes over as president of the Society, who in 1917 assumed this role until the date of his own death in 1942 (Romero Puga y Campio López [46]).

This second point is of particular significance for the religious community, given that some consolidation of their theological beliefs occurs, forming a set of their own exclusive doctrinaire elements of Jehovah's Witnesses, at the same time to identify the social identity members of the Society, definitely separates and differentiates from other Protestant groups. It is also in this second stage where beginning to appear the first problems to those faced by sectarian members, specifically characterized by persecution and legal constraints. The name Jehovah's Witnesses begins to become popular since 1931, when such designation is accepted at an Annual Convention held in the city of Columbus, Ohio, referring to a section of the sacred texts of Isaiah.

A third stage of development of the Society is linked with greater impetus given to the activities of proselytizing. This period coincides with the presidency of the Society by Nathan Knorr, who strengthens the dissemination activities of press, publishing more than twenty-two million pamphlets or five hundred fifteen million copies of the Watchtower and weeklies Awake!, in more than eighty languages. In turn, also during Knorr managing, the official version of the Bible of the Jehovah's Witnesses is published, which is referred to as the New World version of the Bible. In organizational terms, the Company also undergoes transformations during this period. During the presidencies of Russell and Rutherford, the Company had assumed a strongly personal character, a fact that is modified from Knorr. During his presidency, the Company becomes a collegial body, with headquarters in Brooklyn (Romero Puga y Campio López [46]).

Jehovah's Witnesses development in Argentina dates from 1925, when two preachers of the Society reside in the country. Strictly speaking, the location of Jehovah's Witnesses assumes the form of mission in Argentina, given its institutional global church. Originally, the meetings were carried out in private homes, but the growth of the congregation of the faithful led to the need for the formation of Kingdom Halls, as referred to physical spaces where practitioners of the Society congregate (Forni, Mallimaci y Cárdenas [49]).

At present, the Company has a worldwide presence. It is estimated that there are more than fifty-seven thousand congregations spread over two hundred and five countries. In Argentina, the community has Halls of the Kingdom in all provinces. The headquarters and main office is located in the neighborhood of Belgrano, in Buenos Aires. Quantitatively, there are an estimated three million five hundred thousand Jehovah's Witnesses in the world, of which 126 thousand are located in Argentina. At least four hundred fifty thousand devote their full life to religious activity, being only three hundred which are located in our country. Generally speaking, it is possible to identify this religious denomination with members of middle and lower socioeconomic strata (Forni, Mallimaci y Cárdenas [49]).

\section{Organization and Structure}

Society members play a role of "proclaimer". To do this, it is assigned a certain number of weekly hours to be devoted to outreach efforts to perform at a specified territory. From proclaimers assembly, emerge the figure of "precursor minister", whose outreach activity involves dedication hundred hours a month or two hundred thousand annual hours arises. This commitment is shared between preaching activities, Bible studies in homes of other members, visits, etc. A second role in the hierarchy, linked to the previous one, but requires a somewhat greater time commitment; the figure of "special pioneer" requires a commitment of 140 hours per month service, and at least fifty revisits a month. Each local congregation is in charge of a "congregation servant" and its fundamental role is linked to the exercise of the link between the community and the rest of the population. Usually this role is accompanied by an "assistant congregation servant", which has primary responsibility for accounting services performed (De la Peña Fernández y Flores Palma [48]).

In turn, there are the "servants of Bible studies", whose main mission is the development of Bible studies in homes. Generally, the allocation of households is not a personal decision, but rather a designation by the congregation servant. Along with these roles, also you found the "servant of magazines and territory", whose main charge is the dissemination activities run of periodicals Watchtower and Awake! Their tasks focus primarily on providing these materials to other precursors. The "servant of literature" is responsible for providing publishers of materials, especially Bibles and other publications. Monetary income arising from these activities are controlled by the "servant of accounts", responsible for keeping records of the congregation. In organizational terms, each congregation needed resources to support themselves, why the way is through the same member contributions must be ensured. These charges are collected all the congregation meetings held in Kingdom 
Halls or service centers.

There are other minor, such as the "servant of study Watchtower", the "servant ministry school", the "book study conductor" and "speakers" roles. They are integrated into the activities of the congregation, which are coordinated by the committee of the congregation, consisting of the chief servant, the auxiliary and Bible study.

In international terms, the Headquarters of Jehovah's Witnesses is located in the city of Brooklyn, in the United States. Its nuclear organization is made up of a president and a Governing Body. Both have ultimate responsibility with the spiritual, doctrinal and editorial management of the organization. In legal terms, Jehovah's Witnesses are based on the legal form of a corporation. The corporation is called "Watch Tower Society". In this regard, the Company is divided into more than ninety branches around the world. The highest representatives of the Society made world tours, usually more than fifteen countries, with the main objective to confer and give talks to local members (Forni, Mallimaci y Cárdenas [49]).

In each branch lives Jehovah's Witnesses "full-time" devoted to their main activity to the care of each Hall of Kingdom. The doctrine does not establish restrictions on the civil status of these members; they may be married or single, with or without children. Dedication to the tasks of the congregation is unique, and therefore usually done only for a while. Branches offer service to a wider country or area. Each zone is divided into districts, which in turn are divided into circuits again. The administrative organization always rests with the figure of a "servant," which is responsible for the related activities. Congregations are served in turn by a "circuit overseer," which in turn reports to a "district superintendent". Each of them is responsible for visits to all congregations in their respective areas. They are also responsible for coordinating annual meetings, the least two, called assemblies. In all cases, the primary activity is preaching. Such proselytizing is done in person, in a situation of co-presence, and is the primary responsibility to properly transmit knowledge about the Kingdom of God (Forni, Mallimaci y Cárdenas [49]).

\section{Religious Doctrine and Belief System}

The religious doctrine of Jehovah's Witnesses is collected in a book published by the Company, entitled Jehovah's Witnesses in the Twentieth Century. Such publication is a leading publishing works broadcast. In this work it indicates that the source of all truth is the Bible, and that it recovers irrefutably the Word of God. In this regard, it is noted that the Bible is always more reliable than tradition own element. God's name is Jehovah, and Christ is his son, also called the Son of God. Christ is a creature, the first created by God. Unlike proposed by other denominations, they believe that Christ died on a stake, not a cross. Life of Christ is considered a ransom for the souls of all obedient humans; Christ's sacrifice was sufficient to ensure this. The presence of Christ is spiritual, because once dead, he was raised from the dead as a spiritual and immortal only. The future Kingdom of Christ will rule the Earth in peace and justice; Earth will never be destroyed, but the system of things will undergo radical transformations in the battle of Har-Magedon. At that time, people considered fair and approved by God will receive eternal life. Mankind is in "end times" (Romero Puga y Campio López [46]).

On the other hand, human death is considered a consequence of the sin of Adam. The human soul ceases to exist with death. It is considered that hell is the common grave of all mankind; and therefore, the only hope for the dead lies in the resurrection. Only one hundred forty-four thousand people will be able to rule with Christ in heaven, and there is renewed by a new birth as spirit children of God. The Congregation of Christ rises above the figure of Christ. On the other hand, the prayers are addressed solely to God, Christ being an intermediary. The worship of all images as well as spiritualism should be banned. Satan or the Devil is the ruler of the world invisibly. The Christian should keep separate from the world. All human laws are not in conflict with God's laws. Accepting blood transfusion in any way violates the laws of God, and therefore is strictly prohibited. Biblical morality laws must be observed and fulfilled. It is not for the Society to have a clerical class, or have special titles. Regarding the origins, it is considered that man is not a product of evolution, but of God's creation. Christ is the example of how to follow God. Baptism must be done by full immersion as a sign of full dedication to the preaching of his word. The need for all Christians give public testimony of the Bible (Romero Puga y Campio López [46]).

There is a set of beliefs that function as elements of differentiation from other faiths or beliefs, forming a distinctive core propositions. The Bible is the word of God, and is made up of sixty-six books that are inspired by the divine figure and are historically accurate. The Bible is divided into two major sections: Hebrew writings and Christian Greek writings. Its interpretation is literal, with the only exception in cases where the text itself or the context in which the reference is done is confusing (specially by the symbolic nature of the text). The reference to Jehovah as God's name is due to the repetition of such term in the Bible constantly, at least seven thousand times. The idea of the Trinity is rejected, as also believes that the Holy Spirit is a force emanating from the figure of God. Christ is a divine creature, the first created by Jehovah. Immaculate Conception of Mary is considered real, and therefore Christ is the Son of God and, by inheritance, possessor of divine perfection. Christ's existence is justified from the need to meet three obligations entrusted by God: the need to teach the truth about God; lead a life as a model for life; and die for men to free them from sin and death, resulting from the Adam's inheritance (Beckford [47]).

The existence of Jesus also explains the existence of Satan or the devil, fallen angel who uses deception to degenerate men. The most common form of cheating is the profession of a false religion. Idolatry of ethnic groups, nations or political 
movements of any kind is also a form of cheating.

The Earth was created by God to be inhabited by men and the care with justice. In this sense, the Earth can be never destroyed, as the Lord does not make creations in vain. However, sin has led to the creative plan of God is affected. Therefore, with the battle of Har-Magedon this situation will end. More than two billion people will die. Some people have been chosen by the Lord to go to Heaven, and from there to exercise the government of the world with Christ. The number of those chosen will be a hundred and forty and four thousand. The rest of the people who are saved will govern freed from iniquity. Salvation is a reward for the obedience of the believer and not based solely on faith. Disobedience is considered a sin. The conversion of faith is paramount, but also just for the consecration to the service of preaching is that the person is evaluated by God and worthy or not of eternal life. The year 1914 marks a historic milestone, since Russell considers that that year marked the beginning of the final path to the destiny of humanity, which is the Kingdom of Christ on Earth. However, Christ has spiritual existence after the resurrection, why his Kingdom is also spiritual. The endpoint is the Millennial Reign of Christ. In this sense, "this spiritual theocracy is both obedience and service must be salvific. Watchtower is inscribed within this immanent theocratic system; as bearer of divine truth, the faithful must obey your organization and strive within it work in theocratic "(Forni, Mallimaci y Cárdenas [49]).

\section{Common Religious Practices}

Baptism is a religious practice initiation, but is only performed when it is considered that the believer has sufficiently studied the Word of God. In this sense, baptism is a public statement of commitment to service of the Lord, why is rejected infant baptism. Generally, baptisms are performed in mass meetings, carried out in broad physical spaces such as stadiums or theaters, and is done by full immersion (Forni, Mallimaci y Cárdenas [49]).

The ceremony of the Lord's Supper is held once a year, the day of the Passover according to the Jewish calendar, once the sun has hidden and the full moon appears. The ceremony is performed as a symbol of the Last Supper that Jesus celebrated before his death, and for the execution of the ceremony using unleavened bread and wine, both symbols of the body and blood of Christ is necessary. This ceremony is performed only by those who hope to be part of the elect to exercise the co-government with Christ in heaven, that is, part of the one hundred forty-four thousand selected for it. However, the selection is not by any particular authority of the congregation, but results from the individual's own decision, which under his own conscience and personal relationship with God, assumes that sentence.

Almost all the religious practices of the congregation are linked to proselytism and expansion. In this respect, obedience to Jehovah is expressed through the preaching of his word. In turn, in "Kingdom Halls" they hold meetings and training activities related to the proclamation of biblical texts take. Fortnightly, members congregate in classrooms to study the Watchtower publication. In turn, the meetings are also used for training proclaimers, with the aim of obtaining better tools to develop their tasks proclamation. Generally, the difficulties encountered in the exercise of proselytism and some possible solutions are proposed and shared. The Company has the Theocratic Ministry School, which provides a deepening education and training for the exercise of service and allows assume more and more important responsibilities in the organization. There are open and public meetings proclamation where preaching is addressed to the attendees who have been invited. In meetings, collections of offerings are made, although most classrooms have polls in which members can make their voluntary contributions (Forni, Mallimaci y Cárdenas [49]).

In specific cases, small groups of believers conducts Bible studies in their homes once a week. However, most believers pray almost every moment of their daily lives. Prayer is only allowed if it is directed to the Lord, and not based on the repetition of forms or memorized prayers, but rather in the formulation from the heart. Jehovah's Witnesses take an apocalyptic position. That's why any practical activity "in this world" is considered irrelevant at solving temporary problems. In this sense, the welfare activities are rejected; only the future life in the Kingdom of God can solve all human needs.

From everyday life, Jehovah's Witnesses meet a significant number of precepts that function as channels of behavior and individual and social behavior. Much of problems and discrimination that members of this confession meet are linked to compliance with those regulations. Undoubtedly, the most controversial of all is linked to the prohibition on receiving blood transfusions. Faced with the need to receive, the Jehovah's Witness is able to choose his own death, and if so, is considered a martyr. Life, the soul, is located in the blood, why the idea of blood transfusion is a practice where the very essence of the believer is affected. The prohibition of blood involves incorporating both third parties such as itself, if it has been previously stored (Forni, Mallimaci y Cárdenas [49]).

\section{Social Practices}

Another highly controversial point is linked to the wider political and social participation. Jehovah's Witnesses consider themselves members of a Universal Theocratic Kingdom, which was initiated by Christ himself in 1914. Therefore, participation in political or social activities is quite limited. Jehovah's Witnesses respect the set of institutions and under it, they comply with the payment of taxes or respect the authority of the state apparatus at all levels. However, to participate in elections or exercise political functions are not acceptable practices (Romero Puga y Campio López [46]).

However, compliance with these civic or political 
obligations finds its limit in breach of the rules proposed by the divine plan, why certain practices are prohibited. Saluting the flag, sing the national anthem or any other symbolic activity accession constitute violations of the precepts of the Theocratic Kingdom, and therefore are formally and expressly prohibited. Any symbol of adherence to the state or nation, and even the practice of activities or sports competitions, also is restricted. In general, the most critical point has been linked to the need to comply with compulsory military service; in the case of Argentina, only from the derogation in question on the grounds of conscientious objection, this issue became less significant.

The religious foundation of the ban on any symbolic attachment to a nation or a state originates in its conception of theocratic state, whereby all Witnesses are only members of Jehovah's Kingdom. An example would be then, the celebration or birthday celebration, common practice that is profoundly rejected among members because is considered a pagan practice. The birthday celebration is linked with astrology, restricted form of worship, which uses the birth date to indicate aspects of the individual's life both present and future. In this sense it should be understood the prohibition of the commemoration of Carnival, for example, considering it a pagan holiday. In turn, most of the celebrations recovered by the dominant Christian churches, such as Christmas and Easter, are rejected by the Witnesses, since they are in a bond with pagan events (Romero Puga y Campio López [46]).

Members of confession consider the family the most fundamental unit of Jehovah's theocratic government, and therefore, are particularly important. Domestic domination is built around the figure of the father, who is spiritually responsible as material and emotional of all other family members. Validation opinion of the supra-ordination the head of the family, along with active participation in the religious organization are the primary elements that ensure happiness for the Jehovah's Witness. Possibility of mixed marriages where one spouse is Witness can be accepted; in this case, it is only necessary to ensure that children born of the marriage to be freely raised in both religious conceptions, so that then the child will have the elements sufficient to make the decision of choosing their confession trial (Romero Puga y Campio López [46]).

It is accepted divorce as long as an alternative to committing adultery by one of the spouses. Sexual relations are permitted only in the environment of the institution of marriage. It's only accepted heterosexual relations; Homosexuality is considered a sin in the eyes of God. The abortion is also considered an affront to God, and therefore is strictly prohibited.

Considering other aspects of daily life, religion allows the consumption of alcoholic beverages, provided it is not excessive. The abuse of alcohol can lead to the termination of the family unit, and therefore threatens the stability of the theocratic government. They are prohibited the use of any drug, including smoking. They are considered unclean practices, which threaten the physical and emotional health of the believer. Care of the physical aspect is a reflection of spiritual care, and as representatives of God, members must maintain their physical and emotional purity. Based on the Scriptures, point to a number of hygiene and sanitation practices every day, from hand washing to clean the house.

Gambling is strictly prohibited. Other prohibitions are the use of foul language, granting alms or participation in charitable campaigns of all kinds. Social behavior guidelines proposed by the Society Watch Tower Treaty are strictly enforced; in this sense, its failure is considered sufficient for the member does not inherit eternal life of the Kingdom of God motive.

The set of social practices identified from doctrinaire elements, which is best known for its degree of visibility are the activities of religious proselytism. Every member of the Society is a proclaimer, a transmitter of the Word of God, and therefore should devote part of their weekly activity proclamation through home visits time. Proclaiming is done house by house, where a group of Witnesses preaches and provides reading material in clearly defined areas. The task is planned and systematic. With the proclamation activities, each member also performs a characterization of the visited families, according to certain elements which can identify the conversation and the degree of reception given message. These individuations allow then take specific actions of proselytism, by monitoring in the hands of other members of the Society. If verified that view has been successful, and it should be understood that the proclamation has been well received by the person visited, the member can offer a personal Bible study, which is conducted at the home of the person concerned. These activities have great impact. More than three million personal Bible studies in the world per year (Forni, Mallimaci y Cárdenas [49]) are estimated.

The social changes of recent decades have also forced their practices fit proclamation. Faced with the increased employment of women, households are uninhabited much of the day. Therefore, the proclamation now also performed in public or, such as parking lots, shopping malls or factories semi-public places. In these proclamation activities are provided to listeners' publications and invitations to meetings in Kingdom Halls. Expansion strategies are also related to publications. The most relevant are the bi-weekly editions of Watchtower and Awake!, each with about three million eight hundred thousand copies published worldwide (Romero Puga y Campio López [46]).

Both activities proclamation and distribution of publications are carefully recorded and reported by neatly organized communication channels to Headquarters, and are then communicated globally through another publication, the Yearbook.

Congregations are formed from a gradual process of growth and concentration of faithful in a particular geographic region. Originally, when a significant number of believers are warned, a service center, that if he managed to increase the number of members of the Society, could then achieve the status of congregation opens. 


\section{Discriminatory Social Practices Applied to the Case of Jehovah's Witnesses}

The Church of Jehovah's Witnesses has a long tradition of mission in Argentina (Villalpando et al [28]). Since 1924 they are settled in our country. The Church has had a significant amount of inconvenience to practice their religion, leading to various manifestations of religious discrimination.

At the time of the creation of the National Registry of Cults, in 1947, his application was accepted, but the following year was canceled, only to be again recognized recently with the return of democracy in 1984. Some of discriminatory social practices which are subject to the faithful of the Church of Jehovah's Witnesses are:

a) National symbols: the creed of the Church forbids the faithful to worship any other symbol than God. For this reason, and in compliance with one of its most fundamental precepts, Jehovah's Witnesses do not pay homage to the national symbols (National Anthem, Flag). This is especially problematic for children of school age.

b) Medical Treatment: in compliance with biblical precepts, the faithful refuse to receive blood transfusions, only accepting the use of methods called "alternative". This has caused a number of disadvantages for believers of this minority, while not all public and private hospitals accept this condition or are in a position to provide alternative means.

c) Conscientious objection: during the term of compulsory military service, and in connection with the prohibition of worshiping symbols outside the figure of God, many faithful young men asked to be exempted from providing the service indicated. Often such request was denied and, during the last military dictatorship, many faithful were accused of insubordination and subjected to illegal practices, from violence to even prison (generally between 3 and 5 years). Moreover, laws were enacted to compensate those harmed by the military dictatorship (Law 24.043), excluded the Jehovah's Witnesses.

d) Festivities: Jehovah's Witnesses do not recognize dates traditionally recognized by Western Christianity, but organize festivities from what is stated in the Bible, by a lunar calendar. Many times, they are subject to discrimination in the workplace or educational environment because they do not recognize them as religious festivals such days.

\section{Conclusion}

The overlap in the institutional structure of discriminatory patterns that sustain unequal treatment of an individual or group makes up over time to a symbolic universe. From this horizon of meaning are interpreted and signified the behavior patterns of the various social groups in general and communities of the faithful of religious minorities, particularly (Berger and Luckmann [36]).

Thus, institutionalized discrimination becomes the matrix of meanings from which it is interpreted and re-signified all segregationist social practice. This warp, almost invisible at the level of the formation and use of common sense, makes religious discrimination in a complex social phenomenon. The habituation of discriminatory behavior leads to a naturalization of racist original meaning.

The Argentine nation-state proclaimed early as respectful of religious freedom. However, a historical review of the performance of the State bound by this fundamental right seems to reveal a different reality.

The existence of discriminatory social practices confirms the fact of the existence of this social problem. Also, conducting such practices thoughtlessly, in many cases, pays the notion of an institutionalization of these ways of acting, feeling and thinking. Discrimination becomes institutionalized dimension obstructing and delaying the possibility for review and modification.

Moreover, the discrimination of which are subject to Jehovah's Witnesses needs to be analyzed, in political terms, in the broader context of the tension between the forms of linkage between the State and the various minorities are integrated into the social fabric. Thus, the homogenization of the different identities and the formation of a "national" one to concentrate diversity in unity, has been the strategy that the Argentine government has deployed from the moment of its formation, assuming the trend of the French model the laicité (Donatello [2]).

In this sense, the Jehovah's Witnesses religious minority is a paradigmatic case of questioning such policy incorporating various social groups. The religious ethics of Jehovah's Witnesses questioned critically the fundamental bases of construction of national identity, both for its refusal to pay homage to the set of symbols related to the idea of homeland, as well as for his interpellation to the prime institutions historically they served this state monopoly identity construction: education and health.

The school device has been, without doubt, one of the mechanisms which political elites for the realization of a Nation State project were worth. By the late nineteenth century and early twentieth century, the pedagogical positivism developed strategies aimed at "normalization" and as such, created the necessary devices conducive to repress or expel anything that was "different". The influence of "hygienism" visualized early, and managed to settle in the whole school practices and rituals (Puiggrós [51]). These original features remain, to a lesser extent, today. The school still uses hierarchizing structure of diversity, and forms and appoints differences as social stigmas (Villalpando et al. [28]). This is particularly noticeable in the case of Jehovah's Witnesses.

However, in Argentina efforts to resolve discrimination in general and religious discrimination in particular are verified. 
The existence of the National Institute against Discrimination and Xenophobia (INADI) and the development of a National Plan to Combat Discrimination (2006) demonstrate the political and social interest in eradicating the various forms of social discrimination.

\section{REFERENCES}

[1] SHAMMAH, N. Pluralismo y diversidad religiosa: los Testigos de Jehová en la Argentina, X Jornadas sobre alternativas religiosas en América Latina, Asociación de Científicos Sociales de la Religión en el MERCOSUR, Buenos Aires, 2000.

[2] DONATEllo, L. Catolicismo y Montoneros. Religión, política y desencanto, Manantial, Buenos Aires, 2010.

[3] MALLIMACI, F. "Religión, catolicismo y sociedad civil en Argentina: entre la nación católica y la reconstrucción plural de los lazos sociales" en Revista Argentina de Ciencia Política, nro. 5/6, Buenos Aires, Eudeba, 2002.

[4] PETTIGREW, T. y TAYLOR, M. Discrimination, en Encyclopedia of Sociology, Vol. 1, New York, Gale, Cengage Learning, 2001.

[5] PETTIGREW, T., "New Black-White Patterns: How Best to Conceptualize Them?" en Annual Review of Sociology, 1985.

[6] ANTONOVSKY, A. The Social Meaning of Discrimination, Phylon, New York, 1960.

[7] HEPPLE, B., CHOURDHURRY, T. Tackling religious discrimination: practical implications for policy makers and legislators, Home Office Research, Study 221, Home Office, London, 2001.

[8] ROBBERS, G. Key Issues Tackling Discrimination on Grounds of Religion, Institute for European Constitutional Law, University of Trier, 2000

[9] FEAGIN, J. R., and C. B. FEAGIN. Discrimination American Style: Institutional Racism and Sexism, Krieger, Malabar, 1986.

[10] TODOROV, T. Nosotros y los otros, Siglo XXI, México D. F., 1991.

[11] GRÜNER, E. "Racismo / modernidad: una historia solidaria", en Cuadernos del INADI, Nro. 1, Abril 2010.

[12] BAUMAN, Z. Comunidad, Siglo XXI, Buenos Aires, 2003.

[13] UN UNITED NATIONS, Declaration on the Elimination of All Forms of Intolerance and of Discrimination Based on Religion or Belief. Online Available: http://www.un.org/documents/ga/res/36/a36r055.htm. Online Available from: www.un.org

[14] DOMENECH, E. El multiculturalismo en Argentina: Ausencias, ambigüedades y acusaciones, Centro de Estudios Avanzados, Universidad Nacional de Córdoba, en Estudios, $\mathrm{N}^{\mathrm{o}} 14$, pp. 33-47, 2003.

[15] LISCHETTI, M. Antropología, Buenos Aires, Eudeba, Buenos Aires, 2006.
[16] FOX, J. Religion, civilization and war: 1945 through the new millennium, Lexington Books, New York, 2000.

[17] JUERGENSMEYER, M. Terrorismo religioso: el auge global de la violencia religiosa, Siglo XXI, Madrid, 1997.

[18] GREENWALT, K. Discrimination and reverse discrimination, Knopf, New York, 1988.

[19] LITTLE, M. Measuring racial discrimination, The National Academies Press, Washington, D.C., 1991.

[20] TURNER, B. La religión y la teoría social. Una perspectiva materialista, Fondo de Cultura Económica, México D.F., 2005.

[21] HAYNES, R. Discrimination and harassment, Greenwood Publishing Group, New York City, 1994.

[22] HAGEN, R. Discrimination against competent women, Journal of Applied Social Sciences, Volume 5, Issue 4, 362-377, December, 1977.

[23] LUNDAHL, M. y WADENSJO, E. Unequal treatment: a study in neo-classical theory of discrimination, New York University Press, New York City, 1984.

[24] BLANCARTE, R. "Discriminación por motivos religiosos y Estado laico: elementos para una discusión”, en Estudios Sociológicos, vol. XXI, núm. 62, mayo-agosto, El Colegio de México, 2003.

[25] HORBATH, J. La percepción sobre la discriminación. Las percepciones sobre las diferencias físicas en la Ciudad de México, CONAPRED, México D.F., 2007.

[26] GRACIA, A. Discriminación a grupos minoritarios religiosos en México, CONAPRED, México D.F., 2007.

[27] BLANCARTE, R. "Libertad religiosa, Estado laico y no discriminación", Cuadernos de la igualdad $\mathrm{N}^{\circ}$ 9, Consejo Nacional para prevenir la discriminación, México, 2008.

[28] VILLALPANDO, W. et al. La discriminación en Argentina. Diagnósticos y propuestas, Eudeba, Buenos Aires, 2006.

[29] MALLIMACI, Fortunato (2007) Creer y no creer: los universos religiosos y simbólicos en el Río de la Plata. La comparación entre Argentina y Uruguay, VII Jornadas de Sociología de UBA, Noviembre, unpublished, 2007.

[30] RODRÍGUEZ SALAZAR, Tania y GARCÍA CURIEL, María de Lourdes (comp) Representaciones Sociales. Teoría e Investigación, Universidad de Guadalajara, México D.F., 2007.

[31] RODRIGUEZ ZEPEDA, J. Un marco teórico para la discriminación, CONAPRED, México D.F., 2006.

[32] BOURDIEU, P. Razones prácticas. Sobre la teoría de la acción, Anagrama, Barcelona, 1997.

[33] MOUFFE, Ch. El retorno de lo político: comunidad, ciudadanía, pluralismo, democracia radical, Paidós, Barcelona, 1999.

[34] MATTEUCCI, N. "Constitucionalismo”, en BOBBIO, N. y N. MATTEUCCI (Comps.) Diccionario de política, vol. 1, México D.F., Siglo XXI, 1981.

[35] ARENDT, H. Los orígenes del totalitarismo, Alianza, Madrid, 2006. 
[36] BERGER, P. y LUCKMANN, T. La construcción social de la realidad, Amorrortu, Buenos Aires, 2006.

[37] GIDDENS, A. Modernidad e identidad del yo. El yo y la sociedad en la época contemporánea, Península, Barcelona, 1995.

[38] BECKER, G. The economics of discrimination, Chicago University Press, Chicago, 1971.

[39] DOLLARD, J. Caste and class in Southern Town. Garden City, Doubleday, New York City, 1957.

[40] PINCUS, F. Race and Ethnic Conflict. Contending Views on Prejudice, Discrimination and Ethnoviolence, Westview Press, Boulder, 1994.

[41] LEVI-STRAUSS, C. Antropología Estructural, Fondo de Cultura Económica, México D.F., 1983.

[42] RODRÍGUEZ ZEPEDA, J. ¿Qué es la discriminación y como combatirla?, CONAPRED, México D. F., 2004.

[43] FEIERSTEIN, D. Seis estudios sobre genocidio, Editores del Puerto, Buenos Aires, 2008.

[44] BARRER, E. Los nuevos movimientos religiosos: una introducción práctica, Her Britannic Majesty's Stationary Office, London, 1989.
[45] BIDART CAMPOS, G. Tratado Elemental de Derecho Constitucional, Ediar, Buenos Aires, 1992.

[46] ROMERO PUGA, J. C. y CAMPIO LÓPEZ, H. Los voceros del fin del mundo. Testigos de Jehová: discurso y poder, Libros de la Araucaria, México D.F., 2010.

[47] BECKFORD, J. The Trumpet of Prophecy: A Sociological Study of Jehovah's Witnesses, The Chicago University Press, Chicago, 1975.

[48] DE LA PEÑA FERNÁNDEZ, C. y FLORES PALMA, N. Testigos de Jehová: organización por necesidad, Universidad Autónoma Metropolitana, Iztapalapa, 2003.

[49] FORNI, F.; MALLIMACI, F. y L. CÁRDENAS (coordinadores). Guía de la diversidad religiosa de Buenos Aires, Biblos, Buenos Aires, 2003.

[50] SCHARF, M. Belief and exclusion. Combating religious discrimination in Europe, Northumbria University, European Commission and European Network Against Racism, London, 2003.

[51] PUIGGRÓS, A. ¿Qué pasó en la educación argentina? Buenos Aires: Galerna, Buenos Aires, 2003. 